\title{
The Development of Blended Learning Implementation Questionnaire at the Universitas Negeri Medan
}

\author{
Abdul Hamid K ${ }^{1}$, Tiur Malasari Siregar ${ }^{2}$, Jamalum Purba ${ }^{3}$, Budi Ali Mukmin ${ }^{4}$ \\ (wr1@unimed.ac.id ${ }^{1}$, tiurmalasarinew2019@gmail.com²,jp64.purba@gmail.com³ \\ ${ }^{1}$ Department of Engineering Education, Universitas Negeri Medan, Indonesia \\ ${ }^{2}$ Department of Mathematics, Universitas Negeri Medan, Indonesia \\ ${ }^{3,4}$ Department of Chemistry, Universitas Negeri Medan, Indonesia
}

\begin{abstract}
The purpose of this study was to produce a questionnaire instrument that was used as a measure of the implementation of Blended Learning among lecturers and students in Universitas Negeri Medan and to know the validity of the instruments developed. The method used is Research and Development by adopting the Borg and Gall models. The stages that are passed are limited to the preliminary stage, instrument design, and instrument development. In the preliminary stage carried out in Universitas Negeri Medan identifying the components of the implementation of Blended Learning, the design stage compiles the instrument indicators as a measurement tool for Blended Learning by developing 5 components of the evaluation of the implementation of Blended Learning that has been determined. At the instrument development stage, an expert test was conducted to assess the validity of the instrument content in the form of a questionnaire aimed at lecturers and students. The instrument was validated by 4 experts then the content validity was calculated with the Aiken V formula. From the calculation results, it was found that the lecturer questionnaire instrument of 40 items there are 36 items have adequate content validity and student instrument questionnaire of 30 items there are 28 items have adequate content validity.
\end{abstract}

Keywords: Blended Learning, Evaluation, Implementation

\section{Introduction}

Higher education is one of the educational institutions in the national education system. Higher education institutions are obliged to organize education, research, and community service as stipulated in Law Number 20 the Year 2003 concerning the National Education System [1]. The main aim of higher education is to facilitate student learning [2]. To carry out its obligations, tertiary institutions must be supported by synergistic cooperation from all universities.

Universitas Negeri Medan is encouraging its lecturers to provide teaching with the Blended Learning model. Blended learning is a knowledge transfer program that utilizes more than one method to provide information to students [3]. Generally, blended learning is considered as learning that combines face-to-face systems with mediation technology instruction[4]. Many 
researchers from Universitas Negeri Medan have succeeded in applying this Blended Learning model.

Blended Learning is considered capable of being a facility that can help the learning process at Medan State University into learning that can answer the challenges of the Digital Era 4.0. Where in this era all students and lecturers were demanded to be IT literate. Students who have graduated and want to enter the world of work must be able to compete in all fields. We must be able to follow the rapid progress of the times. This can be seen from various industries starting to touch the virtual world, in the form of human, machine, and data connectivity which is better known as the Internet of Things (IoT).

Therefore, to face the industrial revolution 4.0 requires a variety of preparations, including appropriate methods of learning education. Appropriate learning innovations will be able to arouse the independence and confidence of students who have tried to find and explore learning resources not only from lecturers. As explained by Dalyono[5], innovative learning strategies can make it easier to achieve learning competencies, because they can attract and arouse student motivation in learning. This assumption is what led to Blended Learning to be an option when learning is not enough just face to face.

To ensure the accuracy of the running and effectiveness of this model, the researchers made an evaluation instrument for the implementation of the Blended Learning model at Universitas Negeri Medan. The initial stage in this evaluation is developing an evaluation instrument for the implementation of blended learning for lecturers and students. The existence of research instruments is a very important part because research instruments are tools that are used to collect, examine, investigate an issue that is being investigated. Instruments play a very important role in determining the quality of a study, as well as aids used by researchers to collect data by taking measurements[6]. A good instrument must have and meet the criteria as a good instrument, which is valid and reliable. A good instrument will affect the quality of a research result. The function of the instrument is to reveal facts into data so that if the instrument has good quality in the sense of valid and reliable, the data obtained will be under the facts or actual events in the field.

\section{Method}

The research method used is the Research and Development of Borg and Gall. Development research is an activity of developing a new product or improving an existing product [7]. Of the ten stages in the Borg and Gall model, this research development is limited to the third stage. The development carried out by researchers is the creation of an implementation instrument in the form of an evaluation questionnaire for the implementation of blended learning tools for lecturers and students. The development of instruments requires a strong theory to underlie a construct of the phenomenon to be measured, for the birth of a good and relevant instrument [6]. The development of the blended learning questionnaire went through several stages, namely 1) Preliminary research, 2) Questionnaire instrument design 3) Questionnaire instrument development. 


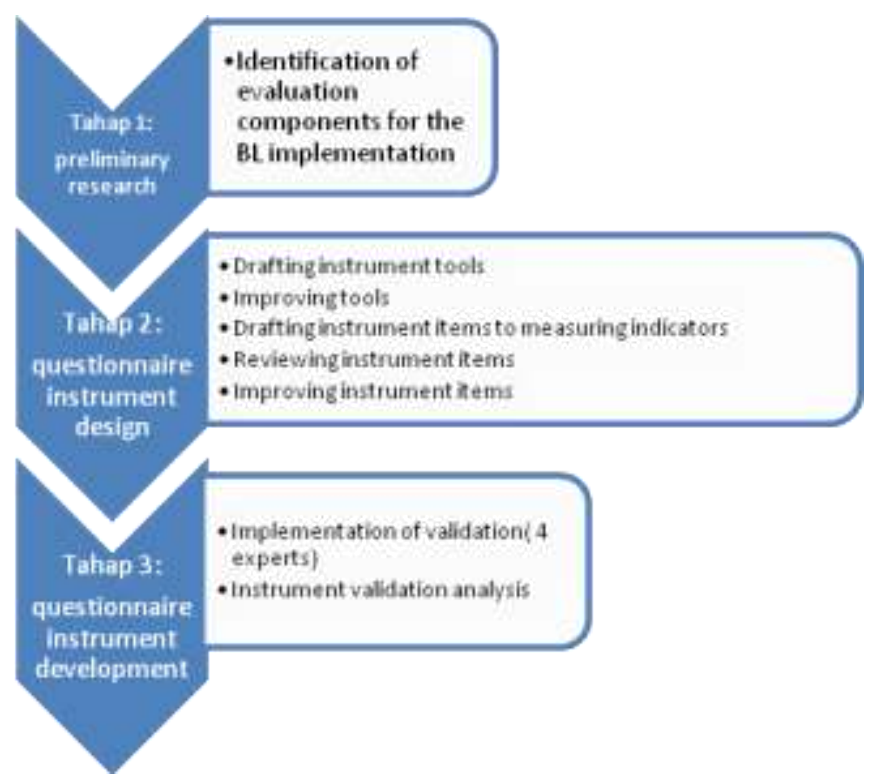

Fig.1. Research stages of questionnaire instrument development

Blended learning in the field of Universitas Negeri Medan has become a benchmark for the need for an instrument to evaluate the implementation of blended learning from lecturers and students. One of the lecturers' performance is assessed through four aspects namely performance in teaching and lecturer capacity [8]. Therefore, it is necessary to study the identification of evaluation components of the implementation of blended learning starting from the measurement of needs, study of literature and consideration in terms of value. The purpose of the study of needs measurement in the field so that the use of instruments is right on target. A literature study is carried out through an analysis of important concepts in the implementation of blended learning and reviewing theories about blended learning and similar research products in the form of research documents or evaluation results. The results of the research will be a reference in developing the instrument. The evaluation components in blended learning include system assessment, program planning, program implementation, program improvement, and program certification [9].

After determining the evaluation component, it will be developed into an open questionnaire instrument tool for lecturers and closed to students. An open questionnaire that gives the opportunity for the respondents to answer in their sentences, questionnaire arranged in such a way that respondents are free to express their opinions [10]. The questionnaire contains the principal questions or statements that can be answered or responded to by respondents freely [11]. The questionnaire instruments made will be divided into two namely instruments that will be addressed to lecturers and instruments that will be addressed to students. Furthermore, the tools are refined to minimize bias. After that, the tools are manifested into the indicator items questions/ statements on 
the questionnaire and then refined in the form of questionnaires to lecturers and statement questionnaires to students. The purpose of the question questionnaire was made to facilitate researchers in describing the state of the implementation in detail and to see the responses of the implementation of blended learning among students.

At this stage, it is a process of testing the content validity of the instruments that have been made. Content validity was carried out to confirm whether the contents of the questionnaire were appropriate and relevant to the purpose of the research. The validity of the content indicates that the content reflects the complete set of attributes studied and is usually done by seven or more experts [12]. Validation was carried out by 5 experts and measured by the Aiken's V formula.

\section{Results and discussion}

The target in this study was to obtain a questionnaire instrument to measure the effectiveness of blended learning in Universitas Negeri Medan. The evaluation components in blended learning are as follows:

Table 1. Evaluation Components of the Blended Learning Implementation

\begin{tabular}{ll}
\hline evaluation components & evaluation aspects \\
\hline System Assessment & - Purpose \\
& - Human Resource Needs \\
& - Environment's Supports \\
Planning Program & - Lecturer Preparation \\
& - Student Preparation \\
Implementation Program & - Introduction of hardware and software for lecturers and \\
& - students \\
Improvement Program & - Implementation of Blended Learning for lecturers \\
& - Implementation of Blended Learning for students \\
Certification Program & - Physical appearance \\
& - Reliability level \\
& - Level of response speed \\
&
\end{tabular}

By adopting an evaluation component of the implementation of blended learning, an instrument was developed that aims to find out how Blended Learning is implemented at Universitas Negeri Medan to determine the suitability of the RPS that has been determined with its implementation in the field, to find out how the lecturer assesses the affective, cognitive, and psychomotor aspects in Blended Learning, to find out the percentage of the presence of lecturers and students in the implementation of Blended Learning and to find out the inhibiting and supporting factors in the implementation of Blended Learning at Universitas Negeri Medan. The 
instrument targets are lecturers and students who carry out learning using the Blended Learning model at Universitas Negeri Medan.

To facilitate the preparation of instruments to be developed, it is necessary to use the instrument development metric or instrument tool [7]. After conducting a study of the needs and considerations, a tool was organized which had been adopted from the evaluation component of the blended learning implementation. The tool component of the implementation questionnaire in blended learning for lecturers is organized into four big points namely: (1) implementation of Blended Learning at Universitas Negeri Medan, (2) conformity between RPS that has been determined by its implementation in the field, (3) ways Lecturers Assess Affective, Cognitive, and Psychomotor Aspects in Blended Learning, and (4) inhibiting and Supporting Factors in the Implementation of Blended Learning at Universitas Negeri Medan

Meanwhile, the questionnaire among students aims to see the response to the implementation of blended learning applied by lecturers in lectures while still considering the objectives of developing the questionnaire. The purpose of the response questionnaires to students to see the extent of the achievement of the implementation of the class aimed at the target of blended learning implementation.

After completing the instrument component grid, the draft observation indicator items are arranged in the form of questions and statements. For the questionnaire for the implementation of blended learning, lecturers are composed of 40 indicators and questionnaires for the implementation of student blended learning are composed of 30 indicators. The stage of compiling to refining the indicators is carried out by taking into account the measurement, description of conditions, measurable activities or behavior.

After the instrument design is complete, the final stage in the research development of the instrument is carried out in the form of testing the instrument, namely the expert validation test to assess the content validity. Content validity reflects the representation and relevance of a set of items used to measure a concept carried out through a rational analysis of the contents of the test through an expert panel assessment.

The validation of the questionnaire instrument for the implementation of blended learning was carried out by 5 experts who were experienced with Focus Group Discussion (FGD) activities. The validators score the accuracy of the instrument with indicators that have been made. The highest score is 5 and the lowest score is 1 . The assessment results from the experts are processed using the Aiken V formula to obtain a content validity score. Aiken's V formula to calculate the contentvalidity coefficient based on the results of an expert panel's evaluation of $n$ people on an item in terms of the extent to which the item represented the measured extract[13]. The formula proposed by Aiken is as follows [14].

$$
\mathrm{V}=\sum \mathrm{s} /[\mathrm{n}(\mathrm{c}-1)]
$$

Where $\quad \mathrm{S}=\mathrm{r}-\mathrm{lo}$

Lo $\quad$ lowest validity score (e.g. 1)

C = highest validity score (e.g. 5)

$\mathrm{R} \quad=$ the score given by the assessor 
The coefficient value of Aiken's $\mathrm{V}$ range between 0 and 1 can be considered to have adequate content validity. The results of the analysis of the content validity of the questionnaire instrument for the implementation of blended learning for lecturers using the Aiken V formula showed that from the 40 item indicator questions and statements, 34 items are considered to have adequate content validity with a value range of 0.60 - 0.85 . The results of the FGD also provide additional input or points related to the assessment for inhibiting and supporting factors components more specifically to get a generalization from the real situation. The FGD also asked for several questionnaire indicators in the form of the Gutman scale to be changed into an open questionnaire in the form of questions because they are needed to emphasize the answers. After making improvements and input from the validator, 36 questions and statements were obtained for the lecturer questionnaire instrument.

The results of the content validity of the questionnaire instrument for the implementation of blended learning for students were also carried out using the Aiken $\mathrm{V}$ formula. The results show that of the 30 statement indicators compiled in the form of a Likert scale, only 28 were judged to have adequate content validity in the range of $0.70-0.90$. The results of the FGD did not provide much input into student instruments, only revised a few sentences of negative statements.

With the completion of the questionnaire instrument development stage, the stages in the research are finally done. The questionnaire instrument is ready for trials. The distribution process of questionnaires to lecturers and students is done online via Google Form media. The implementation of a blended learning questionnaire for lecturers may be accessed via the page site https://forms.gle/aQKH4tjRytzZVtVM6. And for students may be accessed via the site page https://forms.gle/hSwjZy9FbHiXsuLn8. Through the distribution of this questionnaire, it is expected that the Medan state university can analyze the state of the blended learning implementation that needs to be known. After obtaining all the information and answers to the researchers' questions, the researchers will make policy changes to the existing obstacles.

\section{Conclusion}

The conclusions from this development research are: (1) Questionnaire instruments for the blended learning implementation has been produced for lecturers and students; (2) The results of the content validation test by experts using the Aiken's formula show that the product of the lecturer questionnaire instrument developed, 34 items were judged to have adequate content validity with a value range of $0.60-0.85$. From the results of FGD input, the instrument points were revised and 36 questions and statements were produced that met adequate content validity; (3) The results of the content validation test by experts using the Aiken's V formula show that the student questionnaire instrument products which were developed, 28 items were considered to have adequate content validity with a value range of 0.70 - 0.90; (4) Questionnaire instruments that have passed the validation stage are distributed online through Google Form. Page site https://forms.gle/aQKH4tjRytzZVtVM6 is for lecturers, and page site https://forms.gle/hSwjZy9FbHiXsuLn8is for students.

From the results of the development of the instrument is expected to be a measuring tool for the blended learning implementation in the field of Universitas Negeri Medan so that it can be a 
study case in making policies around blended learning. Suggestions in this research are: (1) So that every lecturer and student participates in implementing blended learning in aligning the development of the industrial revolution 4.0; (2) the existence of ongoing research to improve the blended learning implementation or other learning methods that support the improvement of the quality and professionalism of HR.

\section{References}

[1] Depdiknas, UNDANG-UNDANG REPUBLIK INDONESIA NOMOR 20 TAHUN 2003 TENTANG SISTEM PENDIDIKAN NASIONAL. Jakarta, 2003.

[2] C. Nygaard and D. Z. Bellini, "A proposed methodology for contextualised evaluation in higher education," Assess. Eval. High. Educ., vol. 36, no. 6, pp. 657-671, 2011.

[3] D. R. Garrison and H. Kanuka, "Blended learning: Uncovering its transformative potential in higher education," internet High. Educ., vol. 7, no. 2, pp. 95-105, 2004.

[4] H.-J. So and B. Kim, "Title Learning about problem based learning: Student teachers integrating technology, pedagogy and content knowledge Learning about problem based learning: Student teachers integrating technology, pedagogy and content knowledge," Source Australas. J. Educ. Technol. Australas. J. Educ. Technol., vol. 25, no. 251, pp. 101$116,2009$.

[5] B. Dalyono, "Strategi Pembelajaran Inovatif untuk Mencapai Kompetensi pembelajaran," 2016.

[6] R. Firdaos, "Metode Pengembangan Instrumen Pengukur Kecerdasan Spiritual Mahasiswa," Edukasia J. Penelit. Pendidik. Islam, vol. 11, no. 2, pp. 377-398, 2017.

[7] Sugiyono, Metode Penelitian dan Pengembangan (research and development). Bandung: Alfabeta, 2016.

[8] T. H. Retnowati, D. Mardapi, B. Kartowagiran, and S. Suranto, "Model evaluasi kinerja dosen: pengembangan instrumen untuk mengevaluasi kinerja dosen," J. Penelit. dan Eval. Pendidik., vol. 21, no. 2, pp. 206-214, 2017.

[9] D. G. H. Divayana, "Evaluasi pelaksanaan blended learning di SMK TI Udayana menggunakan model CSE-UCLA," J. Pendidik. Vokasi, vol. 7, no. 1, pp. 64-77, 2017.

[10] S. Arikunto, "Dasar-dasar Evaluasi Pendidikan," Jakarta Buku Aksara, p. 397, 2011.

[11] S. Syaodih Nana, "Metode penelitian pendidikan," Bandung PT Remaja Rosdakarya, 2013.

[12] H. Hendryadi, "Validitas isi: tahap awal pengembangan kuesioner," J. Ris. Manaj. dan Bisnis Fak. Ekon. UNIAT, vol. 2, no. 2, pp. 169-178, 2017.

[13] L. R. Aiken, "Formulas for equating ratings on different scales," Educ. Psychol. Meas., vol. 47, no. 1, pp. 51-54, 1987.

[14] S. Azwar, "Reliabilitas dan Validitas edisi 4," Yogyakarta: Pustaka Pelajar, 2012. 